\title{
Research On The Application Of Productive landscape In Urban Environmental Design
}

\author{
Jingjing Zhang \\ university of jingdezhen ceramics Jingdezhen in jiangxi province, China;333403
}

Key words: productive landscape; urban environment; design; application

\begin{abstract}
With the progress of urbanization, urban landscape design is also gradually getting rid of stereotyped aesthetic-centered awareness , and focuses more on people's participation and output, In such a situation, the productive landscape will develop rapidly. Its focus on agricultural production can not only makes people relax physically and mentally, but also can carry out the corresponding harvest. At the same time, it is different from the traditional landscape of the aesthetic and the ecological environment of the city to improve the ability to obtain people's favors. Based on the above, this paper analyzes the application of the productive landscape in the urban environment design. The research of this paper has a positive significance to promote the development and application of the productive landscape in urban environment.
\end{abstract}

No.1 Concept of Productive Landscape

Productive landscape is based on agricultural productive work. It's a kind of landscape architecture built on the basis of agricultural production and industrial production. It is based on the production of material, including productive activities, such as farming, forestry, animal husbandry, side-line production and fishery, etc, and some output of resource. It mixes traditional agricultural activities up with urban natural landscape, which can get resources and please people at the same time. Thus, it is an aesthetic and enjoyable city landscape.

Since its emergence, productive landscape has been applied in different cities and has come out from traditional city landscape. Not only does it have aesthetic function, but it also has brought its special productivity into city landscape. In productive landscape, people can do relevant agricultural productive activities, during which people can get some fruit and vegetables, and citizens can get some new mental experience different from traditional landscape. People can feel the turns of seasons more clearly. At the same time, productive landscape has active influence on the improvement of air quality and conservation of water and soil.

No.2 Necessity of Productive Landscape Integrating into Urban Environment

With the development of society and the progress of urbanization, in cities full of high-rise buildings, the loading capacity of lands is amplified. For some landscapes, simplicity and aesthetic characters become their main features. In high-speed-life cities, people expect to do relevant natural productive activities, such as planting and managing crops, after their busy work. On the one hand, they can relax themselves from work, both physically and mentally. On the other hand, they can also get some corresponding material results by paying physical labor and gain the happiness of harvest. Basing on the character of agricultural labor, it provides the opportunity of laboring. At the same time, its aesthetic character is no less than some other traditional landscapes in cities.After being tired of various landscapes in cities, productive landscape can give people a sense of freshness, which raises people's interests unconsciously.

No.3 Application of Productive Landscape in Urban Environment Design

\section{Interactivity and Participation}

In present cities, various city landscapes are all designed by professional designers, even many of them are almost the same. When people are enjoying these landscapes, they just feel them as visitors. However, for productive landscape, from the design of landscape to the the planting of crops, citizens can feel fully involved. In the construction of productive landscape, a large portion belongs to agricultural labor. So people can exercise and fulfill themselves according to these agricultural labors, and prompt the construction and development of productive landscape in a 
certain degree. Great interactivity and participation make people cooperate with each other during the activity, which is not only a reflection of joy of life, but also an embodiment of the progress of social harmony.

For example, the design of Xintiandi Community in Jinan greatly elaborates the participation of people in productive landscape. Inside the community, there is a farm divided into different pieces. People can plant various fruit and vegetables freely on these pieces. After busy work, returning home, having a piece of personal land, planting some vegetables to feed yourself, experiencing the happiness of harvest according to your active participation and cooperation with your family, isn’t that enjoyable?

\section{Ecosystem and Naturalness}

The ecosystem and naturalness of productive landscape are also important factors of its popularity in cities. With the development of society, cities are gradually developing towards industrialization. In cities, where lands are very expensive, ecosystem and natural landscape are rarely seen. Productive landscape includes some crops, which make it possible for people to participate in planting, managing, harvesting crops, etc. It greatly improves the ecosystem of cities, thus improving air quality and other factors. Moreover, it's also an indispensable element for urban sustainable development. Productive landscape makes the ecological chain of cities more complete, thus making it possible for birds and insects to reproduce. With the growth of crops in productive landscape, this big biologic chain will certainly become more abundant. As a result, people can find more amusement and entertainment in cities, which can promote the development of tourism to a certain degree. Productive landscape will also be a sign of ecosystem and naturalness of cities.

For example, Grant Park in Chicago is a typical park of the full application of productive landscape. In Grant Park, according to the topography, rice is plant on the low-lying land. One reason is the convenience of irrigation. The other reason is good view for people to enjoy. In the other even district in the park, corns are plant. The reason is that corn is a sign of the local culture, thus stimulating people's working passion unconsciously. On the other hand, this can make people feel the accomplishment of harvest according to their own labor. All these show the important meaning of the application of productive landscape in cities.

\section{Entertainment and Education}

Productive landscape needs people's management, such as planting, weeding, harvesting, etc. Each stage needs people's participation. In high-speed-life cities, productive landscape makes people relax from tired work, get some exercise, and please people both mentally and physically. People don't have to go to remote villages to feel the growth of crops. Instead, they can experience and participate the planting, managing, harvesting and other stages of the growth of crops in the neighborhood of their own home, which is actually a kind of mental enjoyment. When people are managing crops, they can see every stage of crops, such as planting, sprouting, weeding, watering, fertilizing, fruiting, etc. Once they see the process of crops' growth by themselves, they can feel the magic of life and the magnificence of nature. Without these things, most of people's knowledge is got from books. No matter how good the books are, they cannot give people so vivid experience. At the same time, in the process of managing crops, it requires various tools, which is also a valuable experience for children. They themselves use these tools to help crops grow. The better the crops grow , the better they feel the greatness of laboring and the magic of nature, by seeing the flowers and fruits. All these are beneficial for the growth of children.

For example, in the farming exhibition area of Shekou, Shenzhen , with only three mus of lands, they have planted more than 20 kinds of crops and relevant fruit and vegetables. For instance, they divide some brick walls into smaller areas and plant different kinds of fruit, vegetables and crops in different areas. They have also set up children playing space, where children can exchange planting experience with each other, and learn something about crops' growth habits from some experts. In the process of fertilizing, weeding and harvesting, children can get happiness from 
laboring and learn corresponding knowledge at the same time.

\section{Dynamic Nature and Layer Sense}

Productive landscape has two main characters. One is the dynamic nature of crops' growth; the other is the layer sense for city landscapes. As for the dynamic nature of productive landscape, it refers to the high speed of crops' growth, which makes it possible for people to see changes every day, while observing productive landscape. Take the corn as an example, its growing period is from July to September. In only three months, a corn completes the whole process of growing from a seed to a more than two-meter high crop. In these three months, the growing speed of corns is very high. If there are corns in the neighborhood of people's living environment, we can feel the high-speed growth with our eyes, which is a quick and dynamic process. From light green, to blueish green, finally to dark green, even to dry yellow in the harvest season, the changes of colors show us a dynamic process and add layer sense to the coming of autumn. Its emergence makes us feel the turns of seasons better, shows us the harvest feeling of autumn, and lets us feel the enjoyment, which other landscapes cannot give us.

For example, in Tianhua Community of Taiyuan, there is a small piece of land. It is divided into many different smaller areas by the bituminous road. In these small areas, people can plant many crops, including corns. When people are free, they can weed and fertilize the corns on these fields. They can also feel the growth of corns when they are exercising along the road. The high speed of corns' growth makes people feel its tenacious vitality. With the changes of corns' colors, people can feel the layer sense of the community even the whole city. On the other side of the road is a pool, in which people can plant some lotus and feed some edible fishes. During the process, people can practice their own operational ability, and make the community more colorful at the same time.

No.4 Conclusion

In conclusion, with the development of society, productive landscape is being commonly applied. It can make people experience the enjoyment of laboring and harvesting by doing labor work and make the city full of freshness and vitality. At the same time, it has an active influence on the improvement of urban ecological environment. With the development of society, in the process of urban development towards industrialization, cities are losing their original ecosystem and naturalness. Productive landscape can exactly fulfill people's requirements for ecosystem and naturalness. Moreover, it promotes urban sustainable development to a certain degree. I firmly believe that productive landscape will play an important role in urban environmental design , with the development of urbanization and the improvement of people's ideology.

\section{Reference}

[1]Li Yang. The Application and Research Value of Productive Landscape in Urban Environmental Design[J]. Art and Design (Theory),2012,04.

[2]Shi Yan, Su Jin. The Value of Productive Landscape in Urban Landscape Cases[J].Sichuan Architecture,2013,02.

[3]Ruan Jinming, Huanghuaming. The Research on Land-choosing Strategy of Productive Landscape in Urban Central Area--example of Guangzhou Urban Space[J].Architecture Knowledge,2013,06.

[4]Zhou Zhongxue. The Influence of Agricultural Landscape Change on Ecological Service under the Background of Urbanization--example of Xi'an metropolitan area[J]. Geography of arid area,2015,05.

[5] Bai Dan, Yan Yutao. Study on the Application of Productive Landscape in the Protection and Display of Large Sites in Rural and Remote Areas[J].Huazhong Architecture,2016,02.

[6]Guo Yanqi, Wang Haiying. The Research of Jiangsu Characteristic Agricultural Production Landscape Aesthetics in the New Countryside Construction[J].Art Education Research,2016,09. 